\title{
ON DOMESTIC HISTORIOGRAPHY OF STUDYING THE PROPAGANDA ACTIVITY DURING THE BATTLE OF STALINGRAD
}

\author{
Georgiy A. Kumanev \\ Institute of Russian History of Russian Academy of Sciences, Moscow, Russian Federation \\ Boris U. Serazetdinov \\ Institute of Russian History of Russian Academy of Sciences, Moscow, Russian Federation
}

\begin{abstract}
The paper analyzes the literature of the post-Soviet period, dedicated to the propaganda work of political veterans of the fronts and armies, as well as commanders, and political workers, party and Komsomol organizations directly in the military, in combat orders of units and party bodies of the Stalingrad region during the battle of Stalingrad. The authors highlight the most topical issues studied in historical works from 1991 to the present. New approaches to the analysis of the content, forms, methods and regional features of propaganda work, the degree of its influence on the life and activities of soldiers and the population in the battle of Stalingrad are characterized. The authors denote the leading subject fields of historiography of Soviet propaganda during the war. This, first of all: 1) agitation and propaganda in the rear of the red Army; 2) political and ideological work in the army and Navy; 3 ) propaganda activities in the liberated areas; 4) propaganda work in the temporarily occupied by the enemy territories; 5) counter-propaganda among the soldiers of the Nazi army and the German population. The special attention is paid to the questions of "feedback". The Russian historiography has for the first time started to touch upon the everyday life of various social groups of the Soviet population, psychology of the masses and the individual, mass consciousness of the population, growth of religiosity of the population, military personnel, Patriotic spirit of clergy.

The Great Patriotic War has revealed very clearly the complex diversity of feelings, beliefs and views that distinguish the moral foundations of the patriot. From the beginning of fascist aggression and up to the end of the $\infty$ struggle against Nazi enemies, The Russian Orthodox Church (ROC) had being supported the spirit of patriotism. $\underset{\sim}{ }$ The authors also consider promising areas for further research on the history of propaganda work of the Soviet $\therefore$ state among the soldiers and the population during the battle of Stalingrad.

㝏 Key words: The Great Patriotic War, the battle of Stalingrad, propaganda activity, printing, leaflets, historiography, cultural and educational work, propaganda.

Citation. Kumanev G.A., Serazetdinov B.U. On Domestic Historiography of Studying the Propaganda Activity during the Battle of Stalingrad. Vestnik Volgogradskogo gosudarstvennogo universiteta. Seriya 4, Istoriya. Regionovedenie. Mezhdunarodnye otnosheniya [Science Journal of Volgograd State University. History. Area Studies. International Relations], 2018, vol. 23, no. 2, pp. 199-211. (in Russian). DOI: https://doi.org/10.15688/ jvolsu4.2018.2.18
\end{abstract}




\title{
К ВОПРОСУ ОБ ОТЕЧЕСТВЕННОЙ ИСТОРИОГРАФИИ ИЗУЧЕНИЯ АГИТАЦИОННО-ПРОПАГАНДИСТСКОЙ РАБОТЫ В ПЕРИОД БИТВЫ ЗА СТАЛИНГРАД
}

\author{
Георгий Александрович Куманев \\ Институт российской истории РАН, г. Москва, Российская Федерация \\ Борис Уразбекович Серазетдинов \\ Институт российской истории РАН, г. Москва, Российская Федерация
}

\begin{abstract}
Аннотация. В статье дается анализ литературы постсоветского периода, посвященной агитационнопропагандистской работе как политорганов фронтов и армий, так и командиров, политработников, партийных и комсомольских организаций непосредственно в войсках, в боевых порядках частей и подразделений, и партийных органов Сталинградской области в период Сталинградской битвы. Выделяются наиболее актуальные вопросы, исследуемые в исторических трудах с 1991 г. по настоящее время. Характеризуются новые подходы к анализу содержания, форм, методов и региональных особенностей агитационно-пропагандистской работы, степени ее влияния на жизнь и деятельность воинов и населения в условиях Сталинградской битвы. Авторы обозначают ведущие предметные поля историографии советской пропаганды в годы войны. Это, прежде всего: 1) агитация и пропаганда в тылу Красной Армии; 2) политико-идеологическая работа в армии и на флоте; 3) агитационно-пропагандистская деятельность в освобожденных районах; 4) пропагандистская работа на временно оккупированных врагом территориях; 5) контрпропаганда среди военнослужащих гитлеровской армии и немецкого населения. Не остались без внимания и вопросы «обратной связи». В отечественной историографии впервые стало уделяться внимание повседневной жизни различных социальных групп советского населения, психологии народных масс и отдельного человека, массовому сознанию населения, росту религиозности населения, военнослужащих, патриотическому настрою духовенства.

Великая Отечественная война чрезвычайно рельефно обнажила сложное многообразие чувств и верований, взглядов и убеждений, которые отличают нравственные устои патриота. С началом фашистской агрессии и до конца борьбы с нацистскими врагами свое глубоко призывное, патриотическое слово сказал Русская православная церковь (РПЦ). Также авторы рассматривают перспективные направления для дальнейших научных исследований по проблеме истории агитационно-пропагандистской работы Советского государства среди воинов и населения в период Сталинградской битвы.

Общий замысел статьи и аналитическая обработка материала были осуществлены Г.А. Куманевым. Б.У. Серазетдиновым были представлены фактические данные и сформулированы концептуальные положения по отдельным сторонам трансформации агитационно-пропагандистской работы в период Сталинградской битвы в отечественной литературе.

Ключевые слова: Великая Отечественная война, Сталинградская битва, агитационно-пропагандистская работа, печать, листовки, историография, культурно-просветительная работа, агитация.
\end{abstract}

Цитирование. Куманев Г. А., Серазетдинов Б. У. К вопросу об отечественной историографии изучения агитационно-пропагандистской работы в период битвы за Сталинград // Вестник Волгоградского государственного университета. Серия 4, История. Регионоведение. Международные отношения. - 2018. - Т. 23, № 2. - C. 199-211. - DOI: https://doi.org/10.15688/jvolsu4.2018.2.18

Изучая историю Сталинградской битвы, исследователи, помимо событий битвы, анализировали и тесно связывали с ней политические, экономические и другие вопросы. Исследования историков на конкретных фактах показывали, что коренной перелом в ходе войны был результатом единства усилий со- ветского фронта и тыла, углублялся анализ деятельности Ставки ВГК, военно-стратегических планов противоборствующих сторон, хода оборонительного сражения и контрнаступления под Сталинградом, исторического значения битвы. Актуальной для исследователей была и тема, касающаяся различных 
аспектов агитационно-пропагандистской работы в период Сталинградской битвы. Не уменьшая значимости экономических факторов в победе в Сталинградской битве, следует обратить внимание и на духовный фактор, идеологическую работу на фронте и в тылу. Поэтому обращение к вопросу об историографии изучения агитационно-пропагандистской работы в период битвы за Сталинград становится актуальным на современном этапе.

Оценивая состояние отечественной историографии по этой проблеме, необходимо рассмотреть, как развивалась российская историография вопроса с учетом нового подхода к оценке материала об организации и проведении агитационно-пропагандистской работы среди воинов армии и флота, среди населения и противника в период Сталинградской битвы, так как по-прежнему эта проблема привлекает значительное внимание многих исследователей.

Предпринимаемая нами попытка дать историографический обзор агитационно-пропагандистской работы во время Сталинградской битвы опирается на литературу многообразного характера и масштаба - от фундаментальных изданий до монографий и статей, появившихся в постсоветский период.

Для понимания содержания, характера, форм агитационно-пропагандистской работы во время Сталинградской битвы необходимо изучение как опыта деятельности политорганов фронтов и армий, так и командиров, политработников, партийных и комсомольских организаций непосредственно в войсках, в боевых порядках частей и подразделений, и партийных органов Сталинградской области.

Исследования с 1991 г. по настоящее время построены прежде на неиспользованных ранее архивных материалах и с применением также новых концептуальных подходов. На смену единомыслию пришел плюрализм постсоветской историографии, особенность которого - формирование различных, порой прямо противоположных, взглядов на агитационно-пропагандистскую работу в годы Великой Отечественной войны. Рассматривая в целом особенности развития постсоветской историографии истории агитационно-пропагандистской работы в период Сталинградской битвы, можно выделить три основных направления в этом процессе.
Первое - это активное расширение источниковой базы, которое стало возможным благодаря рассекречиванию архивов и публикации сборников документов. За двадцать шесть лет постсоветского периода проведена значительная работа по введению в научный оборот документальных материалов по истории Великой Отечественной войны. Они были извлечены из ранее недоступных широкому кругу исследователей российских архивов (например, из Президентского архива, а также из архивов силовых ведомств - ФСБ, МО и др.).

Второе - переосмысление официальной концепции истории Великой Отечественной войны, сформированной традиционной историографией, а также важнейших ключевых проблем и событий войны.

Третье - это постановка новых проблем и вопросов в изучении истории агитационнопропагандистской работы в период Сталинградской битвы, которые ранее не ставились историками, а также новые методы и подходы к изучению событий Великой Отечественной войны и ее истории в целом. В частности, к «белым пятнам» относится острая тема в историографии - анализ действенности политико-массового воздействия на разные возрастные, социальные и профессиональные «страты» в период подготовки и проведения Сталинградского сражения. Интересен механизм «обратной связи», проявлявшийся в различных вербальных формах, а также в массовом движении на фронте и в тылу по мобилизации сил и средств на разгром врага.

Л.М. Савушкин в своей работе показывает проблемы и противоречия идеологии советского тыла 1941-1945 годов. В монографии анализируются задачи, формы и методы идейно-политической работы партийных организаций в тылу РСФСР, среди рабочих и жителей села. Он отмечает, что идеологическая и теоретическая деятельность партии в годы войны была поставлена в такие условия, когда исключалась возможность творческих дискуссий и поэтому «здесь истоки идеологической дремы, а то и вовсе глубокой спячки» $[24$, с. 176$]$.

Обращает внимание сборник документов «Советская пропаганда в годы Великой Отечественной войны: “коммуникация убеждения” 
и мобилизационные механизмы». На основе новых, не опубликованных ранее архивных документов как официального, так и личного происхождения раскрываются структура и механизмы функционирования советского пропагандистского аппарата в годы войны. Авторы-составители А.Я. Лившин, И.Б. Орлов отмечают, что важную роль в период войны играла активизация подсознательных, ментальных основ человеческого поведения. Успех в пропагандистской работе достигался тогда, когда органы пропаганды призывали к действиям, которые люди уже были психологически готовы предпринять, когда пропагандистские «послания» ориентировали их «потребителей» в желаемом и ожидаемом для последних направлений [25, с. 7-8]. В статье «Пропаганда и политическая социализация» авторы подчеркивают, что тема «Родина в опасности» проходит через весь фокус советской пропаганды в период Сталинградской битвы [16]. В статье «Советское "пропагандистское государство” в годы II Мировой войны: ресурсные ограничения и коммуникативные возможности» они обозначают ведущие предметные поля историографии советской пропаганды в годы войны. Это, прежде всего: 1) агитация и пропаганда в тылу Красной Армии; 2) политико-идеологическая работа в армии и на флоте; 3) агитационно-пропагандистская деятельность в освобожденных районах; 4) пропагандистская работа на временно оккупированных врагом территориях; 5) контрпропаганда среди военнослужащих гитлеровской армии и немецкого населения. Не остались без внимания и вопросы «обратной связи» [26].

С точки зрения А.С. Горлова, эффективность пропагандистской работы обеспечивалась созданием системы массовой, адресной, многослойной и конкретной пропаганды. Сталинская пропаганда в годы войны в целом учитывала настроения, ожидания, иллюзии и устремления советских людей на фронте и в тылу. Он подчеркивает, что пропагандистские директивы, направляемые сверху вниз, выступали своего рода методом пропагандистского воздействия в силу их неоспоримости $[5$, с. 26]. В целом исследование отношения населения к агитационно-пропагандистским мероприятиям позволило автору выявить как основные просчеты и провалы пропагандистской работы на фронте и в тылу, так и очевидные успехи, проявившиеся в мобилизации населения на фронте и в тылу для достижения победы над немецко-фашистскими захватчиками [5, с. 25].

Б.Н. Ковалев приводит малоизвестные факты из арсенала нацистской пропаганды, как, например, выпуск сборников с текстами антисоветских песен, частушек, поговорок и анекдотов, проведение оккупационной администрацией конкурса по сбору материалов устного народного творчества. Обращаясь к немецким и советским листовкам, он делится наблюдением о том, что действенными оказывались советские листовки, подписанные иерархами РПЦ и известными деятелями культуры [9].

И.И. Широкорад в своем исследовании делает вывод о том, что в экстремальных условиях войны пропаганда усиливается новыми направлениями, такими как пропаганда великодержавности, патриотизма вне классовых основ, исторической преемственности судеб России и СССР и любви человека к своей малой Родине, к своей семье и близким [32, с. 325].

На основе анализа широкого круга источников А.В. Гайдашевым были раскрыты роль и значение местных региональных властей в осуществлении агитационно-пропагандистской деятельности. Показаны основные виды и формы агитации и пропаганды на территории Сталинградской области в разные периоды Великой Отечественной войны, выявлены особенности их функционирования. Особую значимость имеет рассмотрение в диссертации общественного настроения жителей Сталинградской области в 1941-1942 гг., а также в период развернувшегося сражения в междуречье Волги и Дона. В частности, анализ данной составляющей позволил диссертанту выявить эффективность используемых органами власти приемов и методов в идеологической работе с населением, степень восприимчивости к ним и результативность формирования в массовом сознании веры в достижение победы. Исследователь отмечает, что одним из основных средств агитационнополитической работы является периодическая печать. К началу войны на территории Сталинградской области сеть местной газетной периодики включала республиканские газеты «Правда», «Известия», «Комсомольская правда», 3 областные газеты с общим тиражом 
135000 экземпляров, а также 68 районных и 32 фабрично-заводские газеты, издававшиеся на крупных промышленных предприятиях и стройках города [4, с. 18]. Он приходит к выводу, что с развитием событий на фронтах Великой Отечественной войны агитация быстро реагировала на изменившиеся сознание человека войны и приближалась к выполнению конкретных задач. А.В. Гайдашев отмечает, что когда Вермахт подходил к г. Сталинграду, главной задачей для властей стала подготовка города к обороне, а следовательно, органам агитации и пропаганды предстояло сделать все возможное и невозможное для мобилизации трудовых резервов, но при этом сохранив спокойствие в массах $[4$, c. 20$]$.

В исследовании Т.Н. Орешкиной раскрываются направления работы учреждений культуры Сталинграда и области в период Сталинградской битвы [20]. Она отмечает, что для преодоления влияния хорошо продуманной, последовательной и изощренной немецкой пропаганды в период оккупации необходимо было наглядно (художественными, литературными, живописными и иными приемами) ей противостоять. Т.Н. Орешкина приходит к выводу, что на начальном этапе возрождения из руин учреждения культуры остро нуждались не в воссоздании административной системы по культурному строительству, а в усилении политико-просветительной работы среди населения по преодолению влияния вражеской пропаганды периода оккупации, восстановлению доверия к советской власти и скорейшему возобновлению досуговой деятельности, пусть даже во временно приспособленных помещениях [21, с. 14].

Е.Е. Красноженова отмечает, что в условиях, когда практически во всех районах Сталинградской области культурно-просветительные учреждения были разгромлены и не работали, государство потеряло важные рычаги идеологического воздействия на массы, Сталинградским обкомом ВКП(б) была поставлена задача восстановить работу всех политико- просветительных учреждений, особенно изб-читален, парткабинетов, клубов, библиотек [13, c. 405]. Автором обобщены формы и методы организации культурной работы, показаны особенности развития области в военный период, подчеркнуто развитие агитационно-пропагандистских жанров и видов искусства.

В монографии «Сталинградская битва в советской изобразительной пропаганде и военно-фронтовой графике 1942-1945 гг.» Е.В. Огарковой впервые введен в научный оборот новый комплекс источников - художественные изобразительные источники (около 200 рисунков), позволяющие представить взгляды современников на Сталинградскую битву. Она считает, что реалии Сталинградской битвы привели к существенным переменам «в сфере изобразительной печатной пропаганды, затронувшим как сюжетно-тематическую сторону, так и художественный язык произведений»: художники осознали, что «народ стремится знать правду и критически воспринимает не соответствующую действительности информацию» $[19$, с. 76$]$.

А.В. Мошев исследовал проблемы советской пропаганды в переломный период войны. Основной целью у автора было выяснение методов трансформации агитационного внушения из прямого в косвенное, также уделено внимание способам оперативного пропагандистского воздействия и результатам решения проблем. Он показывает недостатки в разъяснении известного приказа № 227. А.В. Мошев отмечает, что документ за подписями командующего войсками Западного фронта генералполковника И.С. Конева и члена Военного совета этого фронта Н.А. Булганина позволяет говорить о кризисе духа и политической неопределенности солдатских масс. С его точки зрения, неграмотное объяснение политической ситуации агитаторами позволило вкрасться в сознание бойцов сомнениям о необходимости дальнейшей борьбы. То, что названо в тексте документа «благодушием», - не что иное, как неопределенность в необходимости борьбы, непонимание роли и значения Сталинградской битвы. Автор показывает недостатки в разъяснении приказа «Ни шагу назад!»: «....Листовка... по содержанию представляет собой образец безграмотности, неряшливости, пестрит грубейшими ошибками и опечатками... Листовки выполнены на низкопробной бумаге, отталкивающих розовых или желтых цветов и, как описано выше, действительно имеют неадекватные данные о состоянии врага, значительно занижена оценка немецкой ар- 
мии». Например, враг назван «раненым зверем», и листовка призывает добить его в период немецкого наступления под Сталинградом. Подобная заниженная оценка противника приводит к неправильному пониманию происходящих событий и, в свою очередь, ведет к лишним жертвам среди объектов агитации. Также А.В. Мошев раскрывает конкретные меры по улучшению адекватности пропаганды $[17$, с. 26,27$]$. Согласно докладной записке особого отдела НКВД Сталинградского фронта в Управление особого отдела НКВД СССР от 8 августа 1942 г. следует, что многие командиры и бойцы рассматривали этот приказ в качестве дополнительного и сильного средства наведения порядка. «Командир пулеметного эскадрона 20 ГвКП, 5 ГвКД ст. лейтенант Компаниес на митинге, посвященном изданию приказа, сказал: “...Приказ тов. Сталина справедливый и своевременный. Я сам теперь буду, невзирая на лица, призывать трусов и паникеров к порядку. Погибнет родина, погибнем и мы. Если в бою мы погибнем, то враг от нашего сопротивления будет нести большие потери. Только упорным сопротивлением можно отстоять родину и родина останется наша...”». Другие думали, что этот приказ нужен был еще раньше. «Красноармеец 1034 С.П. [стрелкового полка] Найман заявил: “...Если бы этот приказ был издан в начале июня, наша дивизия не оказалась бы в Сталинградской области, а крепко дралась бы за Украину..."» [6].

Об этом можно прочитать и в другом донесении - от 14/15 августа 1942 г.: «Работник оперотдела штаба 57 армии, военинженер 2-го ранга Горский после объявления приказа заявил: “...Приказ тов. Сталина издан своевременно и, безусловно, подымет дисциплину в Красной Армии на должную высоту, что даст возможность быстрее изгнать фашистских оккупантов с нашей земли. Отступать больше некуда. Волга - это последний рубеж, здесь нужно умереть или бить врага и идти на запад, другого выхода нет...”» [7].

А.В. Мошев подчеркивает, что документы 1942-1943 гг., посвященные агитационной работе, позволяют говорить о своевременном выявлении недостатков в деятельности и оперативной реакции на возникающие проблемы частного характера [17].
Интересный ракурс представлен в статье О.В. Рябова. Он анализирует образ Волги-матушки в советской пропаганде периода Сталинградской битвы. Автор отмечает, что этот образ использовался в поддержании советской идентичности, в военной мобилизации, в обосновании военного и морального превосходства Красной Армии и в создании образа врага. О.В. Рябов подчеркивает, что успех Красной Армии в битве и в Великой Отечественной войне в целом сделал символический капитал «Волги-матушки» еще более значительным [23].

В отечественной историографии впервые стало уделяться внимание повседневной жизни различных социальных групп советского населения [14], психологии народных масс и отдельного человека, массовому сознанию населения $[10 ; 11]$, росту религиозности населения, военнослужащих, патриотическому настрою духовенства $[2 ; 33]$.

Великая Отечественная война чрезвычайно рельефно обнажила сложное многообразие чувств и верований, взглядов и убеждений, которые отличают нравственные устои патриота. С началом фашистской агрессии и до конца борьбы с нацистскими врагами свое глубоко призывное, патриотическое слово сказал Русская православная церковь (РПЦ). Обращает внимание статья В.А. Керова о деятельности Русской православной церкви в период битвы на Волге в районе Сталинграда, хотя автор, прежде всего, рассматривает историю отношений православной церкви с руководством страны и с оккупационной властью [8].

В диссертации Г.А. Стругова во второй главе «Нравственно-идеологическое воздействие государства на сознание народа» раскрывает значение агитационно-пропагандистской работы по укреплению духовных сил народа, роль церкви в воспитании гражданственности и человека как личности, как субъекта - главного героя в достижении Победы. Он подчеркивает, что «обогащение и совершенствование агитационно-пропагандистской работы по укреплению духовных сил народа являлось важнейшим условием ускорения разгрома врага» [30].

В работах В.Н. Якунина отмечается сила воздействия церкви на сознание прихожан [33; 34]. 
«Вестником военного и морского духовенства» в 2005 г. был подготовлен спецвыпуск, посвященный 60-летию Победы в Великой Отечественной войне. И там был опубликован объемный материал, посвященный Сталинграду, Сталинградской битве [12].

В статье О.В. Назаровой рассматриваются примеры материального и духовного вклада православной церкви и священников в битве за Сталинград. Автор приводит много различных примеров из православной жизни участников Сталинградской битвы, фактов Божьей помощи защитникам Сталинграда [18].

По мнению С.В. Мордвинова, религиозный фактор (патриотическая деятельность Церкви в помощь фронту, защита с оружием в руках Родины православным духовенством и верующими, мощный всплеск национально-патриотических чувств, сопряженных с православной верой) сыграл определенную роль в победе советских войск под Сталинградом [16].

В настоящее время благодаря усилиям историков и архивистов стали доступны, хотя и в ограниченном объеме, архивные документы, и поэтому есть необходимость рассмотреть исследования по нашей проблеме, где, кроме текста, есть и документы в приложениях.

В 2017 г. вышло 7-е издание, дополненное, энциклопедии «Сталинградская битва. Июль 1942 - февраль 1943» [27]. В коллективной работе, возглавляемой М.М. Загорулько, есть статьи, посвященные агитационно-пропагандистской работе на фронте и в тылу, особенностям культурно-просветительной и партийно-политической работы в Красной Армии в течение всей Сталинградской битвы.

Монографическое исследование В.С. Христофорова «Сталинград: Органы НКВД накануне и в дни сражения» основано на недавно рассекреченных материалах из архивов органов безопасности и посвящено мало раскрытой проблеме - деятельности органов НКВД накануне и в дни битвы за Сталинград. В работе также проанализирована проблема контроля органов безопасности за общественными настроениями. Особенно нас интересуют материалы, посвященные работе с немецкими военнопленными [31, с. 131-141].

Обращает внимание сборник серии «Великая Отечественная война: исследования, документы, комментарии». В сборнике, посвя- щенном Сталинградской битве, публикуются материалы двух оперативно-чекистских подразделений НКВД СССР: управления Особых отделов и военной контрразведки и цензуры. Впервые в динамике прослеживаются настроения не только военнослужащих, но и различных групп населения, их ожидания и поведение в экстремальных условиях военного времени. Так, например, во второй книге этой серии в заключительной части публикуются 30 документов, выявленных в фондах Центрального архива ФСБ России: это, прежде всего, документы УНКВД по Сталинградской области, Особого отдела НКВД Донского фронта и материалов «Особой папки». Особенно интересны доклады руководства НКВД СССР в высшие государственные и партийные инстанции страны о событиях накануне и в дни Сталинградского сражения. В третьей книге привлекает внимание статья В.С. Христофорова «Общественные настроения в СССР : 1943 год», в которой автор продолжает исследовать настроения гражданского населения и военнослужащих Красной Армии. Он отмечает, что постепенно менялась общая тональность настроений советских людей - от упадничества к вере в силы Красной Армии в битве и вере в победу; демонстрировалась готовность активнее поддерживать военно-политические и хозяйственные мероприятия руководства страны. Так, в одном из писем со Сталинградского фронта говорилось: «Много героических подвигов войдет в историю нашей Отечественной войны, но такого сплошного подвига, как защита Сталинграда, помоему, история войны не знает». Но в то же время автор приводит и противоположные, пораженческие, негативные настроения. Он, например, цитирует точку зрения красноармейца 106-го гсп Панкова: «Сталинградскую группировку немцев нам не ликвидировать. Немцы все равно прорвутся через нашу оборону и уйдут, потому что у нас нет боеприпасов. В победу над фашизмом я не верю» [3, с. 261, 421472]. Эти документы еще раз подтверждают необходимость пропагандистской работы с различными категориями жителей, которые оказались в страшные дни войны в оккупации.

Т.А. Павлова также рассматривает общественное настроение населения в Сталинграде. Обращает внимание глава «Подготов- 
ка Сталинграда к обороне, борьба с эвакуационными настроениями и частичная эвакуация материальных ресурсов и населения в условиях военного положения», где воспоминания, архивные материалы позволяют более точно охарактеризовать настроение и поведение населения во время оккупации и после изгнания врага [21].

Необходимо обратить внимание на сборник «Сталинградская эпопея: Материалы НКВД СССР и военной цензуры из Центрального архива ФСБ РФ», где впервые публикуются документы, рассекреченные ФСБ РФ, докладные особых отделов фронтов и армий в области общественного настроения и реакции различных категорий военнослужащих на изменение положения на фронте [29].

В работе «Сталинградская битва. От обороны к наступлению» есть глава, посвященная роли идейного фактора в Сталинградской битве. Книга написана авторским коллективом, где руководителем является А.М. Соколов. Авторы отмечают, что основными задачами идейного и морально-психологического вдохновения воинов - защитников Сталинграда летом и осенью 1942 г. были: разоблачение фашистской пропаганды, пытавшейся возродить миф о «непобедимости германской армии»; показ возрастающего боевого мастерства советских воинов и, как следствие этого, усилившегося сопротивления врагу. Также они обращают внимание на разоблачение злодеяний гитлеровцев по отношению к советским военнопленным и мирному населению временно оккупированных советских территорий; информирование воинов о росте экономических и военных ресурсов антигитлеровской коалиции, ее успехов в борьбе против фашизма. Не забывают и о других направлениях: пропаганда героического прошлого нашей Родины, воспитание национальной гордости советских людей; освещение неразрывной связи защитников Сталинграда со всем населением страны [28, с. 361].

В другой коллективной монографии «Военный Сталинград как мировой социокультурный феномен» Р.М. Ламзин отмечает, что политико-идеологическая подготовка действий советских войск в рамках обороны Сталинграда была связана с деятельностью политуправления Сталинградского фронта. Этот главный орган идеологического обеспечения поставил задачу объединения сил личного состава отдельных частей при активной деятельности партийных организаций, что должно было сформировать у защитников города такие чувства, как «стойкость, ненависть к врагу, презрение к смерти, готовность любой ценой остановить фашистские полчища, рвущиеся к Волге». Он также подчеркивает, что одним из средств ведения агитации и пропаганды было использование исторической памяти ведения обороны Царицына в 1918 г. во время Гражданской войны [15, с. 21,22$]$.

В.Н. Бусловский впервые рассматривает проблему преодоления пораженческих и отступленческих настроений, самолето- и танкобоязни в период Сталинградской битвы. Он отмечает, что создавались специальные отряды истребителей танков из наиболее опытных и хорошо подготовленных воинов, личному составу разъяснялись приемы и способы уничтожения танков [1].

Анализ литературы постсоветского периода до наших дней свидетельствует о том, что российские историки внесли определенный вклад в разработку проблем агитационно-пропагандистской работы в период Сталинградской битвы, но имеются и нерешенные задачи. Не случайно эта тема остается еще актуальной.

Усилиями многих российских историков значительно расширены рамки исследований проблем агитационно-пропагандистской работы в период Сталинградской битвы. Важным стало появление интереса к региональной истории: защищаются диссертационные исследования, выходят монографии, проводятся научные конференции, где рассматриваются проблемы пропаганды и агитации в период Сталинградской битвы. Создана солидная база для проведения дальнейших научных изысканий в этой области. Необходимо, прежде всего, продолжить исследование организационной структуры агитационно-пропагандистской работы в период Сталинградской битвы с привлечением новых неопубликованных материалов. Мало изучена деятельность военных советов фронтов (а их было 3) и армий (их было 14). Поскольку в некоторых армиях служили бойцы нерусской национальности, следует продолжить изучение специфики политической работы с учетом этого обстоятельства. 
Недостаточно полно и глубоко раскрыт вопрос о применении устных и печатных форм пропаганды и агитации, об использовании армейских культурно-просветительных учреждений, агитбригад в период оборонительной операции на подступах к Сталинграду (17 июля - 12 сентября 1942 г.), наступательных действий советских войск севернее и южнее города (13 сентября - 18 ноября 1942 г.) и операций «Уран», «Малый Сатурн» и «Кольцо». Необходимо также показать особенности агитационного воздействия с учетом рода войск, в зависимости от складывающейся военной обстановки. Вне поля зрения исследователей осталась и организация контрпропаганды. На настоящий момент в отечественной историографии отсутствуют работы, сочетающие в себе анализ содержания материала, который использовался различными средствами пропаганды и агитации, с количественной оценкой этого материала, а также с новыми подходами к восприятию всех категорий участников Сталинградской битвы. Ждут своего обстоятельного исследования гендерные аспекты агитационно-пропагандистской деятельности в период Сталинградской битвы. Перечисленные выше проблемы требуют внимания историков и дальнейшей углубленной разработки.

\section{СПИСОК ЛИТЕРАТУРЫ}

1. Бусловский, В. Н. Морально-политические факторы, предопределившие стойкость и мужество советского народа и Советской Армии в Сталинградской битве / В. Н. Бусловский// Сталинградская битва: история и значение : Военно-историческая конференция. М. : [4 филиал Воениздата], 2003. -С. 101-105.

2. Васильева, О. Ю. Русская православная церковь в политике советского государства в 19431948 гг. / О. Ю. Васильева. - М. : Ин-т рос. истории PAH, 2001. $-214 \mathrm{c}$.

3. Великая Отечественная война. 1942 год : Исследования, документы, комментарии / отв. ред. В. С. Христофоров. - М. : Изд-во Главного архивного управления г. Москвы, 2012. -616 с.

4. Гайдашев, А. В. Агитационно-пропагандистская деятельность органов власти и управления на территории Сталинградской области в годы Великой Отечественной войны : автореф. дис. ... канд. ист. наук / Гайдашев Александр Валерьевич. - Астрахань, 2013.- $23 \mathrm{c}$.
5. Горлов, А. С. Советская пропаганда в годы Великой Отечественной войны: институциональные и организационные аспекты : автореф. дис. ... канд. ист. наук / Горлов Андрей Сергеевич. - М., 2009. $-27 \mathrm{c}$.

6. Докладная записка ОО НКВД СТФ в УОО НКВД СССР «О реагированиях личного состава частей Сталинградского фронта на приказ № 227» от 8 августа 1942 г. // ЦА ФСБ РФ. - Ф. 14. - Оп. 4. Д. 912. - Л. 160-162.

7. Докладная записка ОО НКВД СТФ в УОО НКВД СССР «О реагированиях личного состава частей и соединений на приказ Ставки» от 14/15 августа 1942 г. // ЦА ФСБ РФ. - Ф. 14. - Оп. 4. - Д. 912. Л. $160-162$.

8. Керов, В. А. Русская православная церковь и сталинградская битва : (К вопросу о роли церкви в развитии общенародного патриотизма) / В. А. Керов // Вестник российского университета дружбы народов. Серия: Международные отношения. 2003. - № 1. - С. 25-37.

9. Ковалев, Б. Н. Повседневная жизнь населения в период нацистской оккупации / Б. Н. Ковалев. - М. : Молодая гвардия, 2011. -619 с.

10. Козлов, Н. Д. С волей к победе: пропаганда и обыденное сознание в годы Великой Отечественной войны / Н. Д. Козлов. - СПб. : Ленингр. гос. обл. ун-т им. А. С. Пушкина, 2002. - 313 с.

11. Кондакова, Н. И. Духовная жизнь России и Великая Отечественная война 1941-1945 / Н. И. Кондакова. - М. : Луч : Фонд 900-летия Рязани, 1996. -202 c.

12. Красник, Л. Сталинградское знамение / Л. Красник, Ф. Андреев // Вестник военного и морского духовенства : Журнал Синодального отдела Московского Патриархата по взаимодействию с Вооруженными Силами и правоохранительными учреждениями. Спецвыпуск, посвященный 60-летию Победы в Великой Отечественной войне. - М. : [б. и.], 2005. - С. 56-75.

13. Красноженова, Е. Е. Исторический опыт реализации социальной политики Советского государства в период Великой Отечественной войны 19411945 гг. : на материалах Нижнего Поволжья : дис. ... д-ра ист. наук : 07.00.02 / Красноженова Елена Евгеньевна. - Астрахань, 2014. - 495 с.

14. Кринко, Е. Ф. Частная жизнь советского человека в условиях военного времени: пространство, границы и механизмы реализации (1941$1945)$ / Е. Ф. Кринко, И. Г. Тажидинова, Т. П. Хлынина. - Ростов н/Д : Изд-во ЮНЦ РАН, 2013. - 362 с.

15. Ламзин, Р. М. Политика и идеология в период Сталинградской битвы: идеалы и реалии борьбы советского народа с нацистскими захватчиками / Р. М. Ламзин // Военный Сталинград как мировой социокультурный феномен : кол. монография. Волгоград : Изд-во ВолГУ, 2017. -С. 14-29. 
16. Мордвинов, С. В. Русская православная церковь на Нижней Волге и Дону в 1941-1953 гг.: возрождение социокультурных традиций : автореф. дис. ... канд. ист. наук : 24.00.01 / Мордвинов Сергей Валерьевич. - Волгоград, 2014. - 29 с.

17. Мошев, А. В. Эволюция советской агитации в переломный период Второй мировой войны 1942 1943 гг. / А. В. Мошев // Вестник Московского государственного областного университета. Серия: История и политические науки. - 2010. - № 2. - С. 25-28.

18. Назарова, О.В.Они прошли войну с верой: православное духовенство в битве за Сталинград / О. В. Назарова // Великая Отечественная война 1941-1945 гг. в судьбах народов и регионов : сб. ст. / отв. ред. А. Ш. Кабирова. - Казань : Ин-т истории им. Ш. Марджани АН РТ, 2015. - С. 443-451.

19. Огаркова, Е. В. Сталинградская битва в советской изобразительной пропаганде и военнофронтовой графике 1942-1945 гг. / Е. В. Огаркова. Волгоград : Издатель, 2011.-184 с.

20. Орешкина, Т. Н. Восстановление и развитие учреждений культуры в Сталинградской области: 1943 - начало 1950-х гг. : дис. ... канд. ист. наук / Орешкина Татьяна Николаевна. - Волгоград, 2009. -199 c.

21. Павлова, Т. А. Засекреченная трагедия: гражданское население в Сталинградской битве / Т. А. Павлова. - Волгоград : Тип. изд-ва «Перемена», 2005. -593 c.

22. Пропаганда и политическая социализация / А. Я. Лившин [и др.] // Отечественная история. 2008. - № 1. - С. 99-105.

23. Рябов, О. В. «Волга-матушка» в советской пропаганде периода Сталинградской битвы / О. В. Рябов // Военная история России: проблемы, поиски, решения : материалы Междунар. науч. конф., посвящ. 70-летию Победы в Великой Отечественной войне, Волгоград, 25-26 сент. 2015 г. В 2 ч. Ч. 1. - Волгоград : Изд-во ВолГУ, 2015. - С. 115-120.

24. Савушкин, Л. М. Идеология советского тыла: проблемы и противоречия, 1941-1945 гг. : (Опыт деятельности партийных организаций тыловых р-нов РСФСР) / Л. М. Савушкин. - Воронеж : Изд-во Воронеж. ун-та, 1990. - 191 с.

25. Советская пропаганда в годы Великой Отечественной войны: «коммуникация убеждения» и мобилизационные механизмы / авторы-составители А.Я. Лившин, И. Б. Орлов. - М. : Рос. полит. энцикЛ., 2007. - $806 \mathrm{c}$.

26. Советское «пропагандистское государство» в годы II Мировой войны: ресурсные ограничения и коммуникативные возможности / А. Лившин [и др.] // The Sovietand Post-Soviet Review. 2012. - Vol. 39. - P. 192-218.

27. Сталинградская битва : июль 1942 - февраль 1943 : энциклопедия / [Загорулько М. М., Усик Б. Г.,
Бормотов А. Л. [и др.]]. - 7-е изд., доп. - Волгоград : Издатель, 2017. - $837 \mathrm{c.}$

28. Сталинградская битва. От обороны к наступлению / [авт. кол. А. М. Соколов (рук.) [и др.]]. M. : ACT, 2014. $-477 \mathrm{c}$.

29. Сталинградская эпопея : Материалы НКВД СССР и военной цензуры из Центрального архива ФСБ РФ. - М. : Звонница-МГ, 2000. - 492 с. - (Серия: ХХ век : История. Лики. Лица. Личины).

30. Стругов, Г. А. Государственно-правовое и идеологическое воздействие государственной системы на сознание народа в годы Великой Отечественной войны : автореф. дис. ... канд. ист. наук : 07.00.02 / Стругов Георгий Александрович. - СПб., 2005. $-25 \mathrm{c}$.

31. Христофоров, В. С. Сталинград: Органы НКВД накануне и в дни сражения / В. С. Христофоров. - М. : Московские учебники и Картолитография, 2008. -240 с.

32. Широкорад, И. И. Центральная периодическая печать в годы Великой Отечественной войны (1941-1945) / И. И. Широкорад. - М. : Изд-во МГУП, 2001. $-330 \mathrm{c}$.

33. Якунин, В. Н. Положение и деятельность Русской православной церкви в годы Великой Отечественной войны 1941-1945 гг. / В. Н. Якунин. Самара : Изд-во «Самарский ун-т», 2001. - 400 с.

34. Якунин, В. Н. Духовное образование в России в годы Великой Отечественной войны / В. Н. Якунин // Педагогика. - 2003. - № 1. - С. 88-91.

\section{REFERENCES}

1. Buslovskiy V.N. Moralno-politicheskie faktory, predopredelivshie stoykost i muzhestvo sovetskogo naroda i Sovetskoy Armii v Stalingradskoy bitve [Moral and Political Factors behind the Resilience and Courage of the Soviet People and the Soviet Army in the Stalingrad Battle]. Stalingradskaya bitva: istoriya $i$ znachenie. Voenno-istoricheskaya konferentsiya [The Battle of Stalingrad: History and Significance. Military-Historical Conference]. Moscow, 4 filial Voenizdata Publ., 2003, pp. 101-105.

2. Vasilyeva O.Yu. Russkaya pravoslavnaya tserkov v politike sovetskogo gosudarstva v 19431948 gg. [The Russian Orthodox Church in Soviet State Policies in 1943-1948]. Moscow, In-t ros. istorii RAN Publ., 2001. 214 p.

3. Khristoforov V.S., ed. Velikaya Otechestvennaya voyna. 1942 god: Issledovaniya, dokumenty, kommentarii [Great Patriotic War. 1942: Studies, Documents, Reviews]. Moscow, Izd-vo Glavnogo arkhivnogo upravleniya goroda Moskvy, 2012. 616 p.

4. Gaydashev A.V. Agitatsionno-propagandistskaya deyatelnost organov vlasti i upravleniya 
na territorii Stalingradskoy oblasti v gody Velikoy Otechestvennoy voyny: avtoref. dis. ... kand. ist. nauk [Propaganda Activities of the Power and Administration Authorities in the Stalingrad Region during the Great Patriotic War]. Astrakhan, 2013. 23 p.

5. Gorlov A.S. Sovetskaya propaganda v gody Velikoy Otechestvennoy voyny: institutsionalnye $i$ organizatsionnye aspekty: avtoref. dis... kand. ist. nauk [Soviet Propaganda during the Great Patriotic War: Institutional and Organizational Aspects]. Moscow, 2009. 27 p.

6. Dokladnaya zapiska OO NKVD STF v UOO NKVD SSSR «O reagirovaniyakh lichnogo sostava chastey Stalingradskogo fronta na prikaz № 227» ot 8 avgusta 1942 g. [Report Note of OO NKVD STF to UOO NKVD USSR "On the Responses of the Stalingrad Front Armies to Order 227" of August 8, 1942]. Tsentralnyy arkhiv FSB RF [Central Arkhive of the Federal Security Service of the Russian Federation], F. 14, Op. 4, D. 912, L. 160-162. URL: http:/ /www.proriv.ru/articles.shtml/documents? docs_nkvd2.

7. Dokladnaya zapiska OO NKVD STF v UOO NKVD SSSR «O reagirovaniyakh lichnogo sostava chastey i soedineniy na prikaz Stavki» ot $14 / 15$ avgusta 1942 g. [Report Note of OO NKVD STF to UOO NKVD USSR "On the Responses of the Personnel of Units and Formations to Order of Stavka (General Headquarters)" of 14-15 August 1942]. Tsentralnyy arkhiv FSB RF [Central Arkhive of the Federal Security Service of the Russian Federation], F. 14, Op. 4, D. 912 , L. 160-162. URL: http://www.battlefield.ru/order-227negative-14-15-08-42.html.

8. Kerov V.A. Russkaya pravoslavnaya tserkov i stalingradskaya bitva ( $\mathrm{K}$ voprosu o roli tserkvi v razvitii obshchenarodnogo patriotizma) [The Russian Orthodox Church and the Battle of Stalingrad (On the Role of the Church in the Development of National Patriotism)]. Vestnik ros. un-ta Druzhby narodov. Seriya: Mezhdunarodnye otnosheniya, 2003, no. 1, pp. 25-37.

9. Kovalev B.N. Povsednevnaya zhizn naseleniya $v$ period natsistskoy okkupatsii [Daily Life of the Population during the Nazi Occupation]. Moscow, Molodaya gvardiya Publ., 2011. 619 p.

10. Kozlov N.D. $S$ voley $k$ pobede: propaganda $i$ obydennoe soznanie v gody Velikoy Otechestvennoy voyny [With the Will to Win: Propaganda and the Everyday Consciousness in the Years of the Great Patriotic War]. Saint Petersburg, Leningr. gos. obl. unt im. A. S. Pushkina, 2002. 313 p.

11. Kondakova N.I. Dukhovnaya zhizn Rossii $i$ Velikaya Otechestvennaya voyna 1941-1945 [The Spiritual Life of Russia and the Great Patriotic War of 1941-1945]. Moscow, Luch Publ.; Fond 900-letiya Ryazani Publ., 1996. 202 p.
12. Krasnik L., Andreev F. Stalingradskoe znamenie [Stalingrad Sky-Sign]. Vestnik voennogo $i$ morskogo dukhovenstva / Zhurnal Sinodalnogo otdela Moskovskogo Patriarkhata po vzaimodeystviyu s Vooruzhennymi Silami $i$ pravookhranitelnymi uchrezhdeniyami. Spetsvypusk, posvyashchennyy 60-letiyu Pobedy v Velikoy Otechestvennoy voyne [Journal of the Military and Naval Clergy / Journal of the Synodal Department of the Moscow Patriarchate for Cooperation with the Armed Forces and Law Enforcement Agencies. Special Issue Dedicated to the $60^{\text {th }}$ Anniversary of the Victory in the Great Patriotic War]. Moscow, 2005, pp. 56-75.

13. Krasnozhenova E.E. Istoricheskiy opyt realizatsii sotsialnoy politiki Sovetskogo gosudarstva $v$ period Velikoy Otechestvennoy voyny 1941-1945 gg.: na materialakh Nizhnego Povolzhya: dis. ... d-ra ist. nauk [Historical Experience of of the Soviet Social Policy Implementation during the Great Patriotic War of 1941-1945 (Based on Materials of the Lower Volga Region). Dr. hist. sci. diss.]. Astrakhan, 2014. 495 p.

14. Krinko E.F., Tazhidinova I.G., Khlynina T.P. Chastnaya zhizn sovetskogo cheloveka $v$ usloviyakh voennogo vremeni: prostranstvo, granitsy $i$ mekhanizmy realizatsii (1941-1945) [Private Life of Soviet People in Wartime: Space, Borders and Mechanisms of Implementation (1941-1945)]. Rostovon-Don, Izd-vo YuNTs RAN, 2013. 362 p.

15. Lamzin R.M. Politika i ideologiya $v$ period Stalingradskoy bitvy: idealy i realii borby sovetskogo naroda s natsistskimi zakhvatchikami [Politics and ideology during the battle of Stalingrad: ideals and realities of the Soviet people's struggle against Nazi invaders]. Tinina Z.P., Razakov V.Kh., Ivanova O.N., Lukonina O.I., Kotelnikova O.Yu., Chekalina N.E., eds. Voennyy Stalingrad kak mirovoy sotsiokulturnyy fenomen: kollektivnaya monografiya [Military Stalingrad as a World Socio-Cultural Phenomenon. Collective Monograph]. Volgograd, Izd-vo VolGU, 2017, pp. 14-29.

16. Mordvinov S.V. Russkaya pravoslavnaya tserkov na Nizhney Volge i Donu v 1941-1953 gg.: vozrozhdenie sotsiokulturnykh traditsiy: avtoref. dis. ... kand. ist. nauk [Russian Orthodox Church on the Lower Volga and Don in 1941-1953: Revival of Socio-Cultural Traditions. Cand. hist. sci. abs. diss.]. Volgograd, 2014. 29 p.

17. Moshev A.V. Evolyutsiya sovetskoy agitatsii v perelomnyy period Vtoroy mirovoy voyny 19421943 gg. [Evolution of Soviet Propaganda during the Critical Period of the Second World War, 1942-1943]. Vestnik Moskovskogo gosudarstvennogo oblastnogo universiteta. Seriya: Istoriya i politicheskie nauki, 2010, no. 2, pp. 25-28. 
18. Nazarova O.V. Oni proshli voynu s veroy: pravoslavnoe dukhovenstvo v bitve za Stalingrad [They Went Through War with Faith: the Orthodox Clergy in the Battle of Stalingrad]. Kabirova A.Sh., ed. Velikaya Otechestvennaya voyna 1941-1945 gg. $v$ sudbakh narodov i regionov: sbornik statey [The Great Patriotic War of 1941-1945 in the Destinies of Peoples and Regions: a Collection of Articles]. Kazan, Institut istorii im. Sh. Mardzhani AN RT, 2015, pp. 443-451.

19. Ogarkova E.V. Stalingradskaya bitva $v$ sovetskoy izobrazitelnoy propagande $i$ voennofrontovoy grafike 1942-1945 gg. [The Battle of Stalingrad in Soviet Pictorial Propaganda and the Military Front-Line Graphics of 1942-1945]. Volgograd, Izdatel Publ., 2011.184 p.

20. Oreshkina T.N. Vosstanovlenie i razvitie uchrezhdeniy kultury $v$ Stalingradskoy oblasti: 1943 - nachalo 1950-kh gg.: diss...kand. ist. nauk [Restoration and Development of Cultural Institutions in the Stalingrad Region: 1943 - early 1950s. Cand. hist. sci. diss.]. Volgograd. 2009. 199 p.

21. Pavlova T.A. Zasekrechennaya tragediya: grazhdanskoe naselenie $v$ Stalingradskoy bitve [Classified Tragedy: Civilians in the Battle of Stalingrad]. Volgograd, Tip. izd-va "Peremena", 2005. $593 \mathrm{p}$.

22. Livshin A.Ya., et al. Propaganda i politicheskaya sotsializatsiya [Propaganda and Political Socialization]. Otechestvennaya istoriya, 2008, no. 1, pp. 99-105.

23. Ryabov O.V. «Volga-Matushka» v sovetskoy propagande perioda Stalingradskoy bitvy ["MotherVolga" in Soviet Propaganda during the Battle of Stalingrad]. Voennaya istoriya Rossii: problemy, poiski, resheniya: materialy Mezhdunar. nauch. konf., posvyashch.70-letiyu Pobedy v Velikoy Otech. voyne, Volgograd, 25-26 sent. 2015 g.: v 2 ch. Ch. 1 [Military History of Russia: Problems, Searches, Solutions. Proceedings of the International Academic Conference Dedicated to the $70^{\text {th }}$ Anniversary of the Victory in the Great Patriotic War (Volgograd, September 25-26, 2015). In 2 Parts. Part 1]. Volgograd, Izd-vo VolGU, 2015, pp. 115-120.

24. Savushkin L.M. Ideologiya sovetskogo tyla: problemy i protivorechiya, 1941-1945 gg.: (Opyt deyatelnosti part. org. tylovykh r-nov RSFSR) [The Ideology of the Soviet Union: Problems and Controversies, 1941-1945.: (the Experience of the Rear Districts of the RSFSR)]. Voronezh, Izd-vo Voronezh. un-ta, 1990. $191 \mathrm{p}$.

25. Livshin A.Ya., Orlov I.B. Sovetskaya propaganda $v$ gody Velikoy Otechestvennoy voyny: «kommunikatsiya ubezhdeniya» $i$ mobilizatsionnye mekhanizmy [Soviet propaganda during the great
Patriotic war: "communication persuasion" and the mechanisms of mobilization]. Moscow, Rossiyskaya politicheskaya entsiklopediya Publ., 2007. 806 p. ("Documents of Soviet History").

26. Livshin A.Ya., Orlov I.B. Sovetskoe «propagandistskoe gosudarstvo» v gody II mirovoy voyny: resursnye ogranicheniya i kommunikativnye vozmozhnosti [The Soviet "Propaganda State" in the Years of World War II: Resource Constraints and Communication Capabilities]. The Sovietand PostSoviet Review, 2012, vol. 39, pp. 192-218.

27. Zagorulko M.M., Usik B.G., Bormotov A.L. et al. (eds.) Stalingradskaya bitva: iyul 1942 - fevral 1943: entsiklopediya [The Battle of Stalingrad. July 1942 - February 1943. Encyclopedia]. Volgograd, Izdatel Publ., 2017. 837 p.

28. Sokolov A.S. et al. Stalingradskaya bitva. Ot oborony k nastupleniyu [The Battle of Stalingrad. From Defense to Offensive]. Moscow, AST Publ., 2014. $477 \mathrm{p}$.

29. Stalingradskaya epopeya: Materialy NKVD SSSR $i$ voennoy tsenzury iz Tsentralnogo arkhiva FSB RF. Seriya: XX vek: Istoriya. Liki. Litsa. Lichiny [The Stalingrad Epic: Proceedings of the NKVD and Military Censorship of the Central Archive of FSB of the Russian Federation. Series: $20^{\text {th }}$ Century. History. Faces. Masks]. Moscow, Zvonnitsa-MG Publ., 2000. 492 p.

30. Strugov G.A. Gosudarstvenno-pravovoe $i$ ideologicheskoe vozdeystvie gosudarstvennoy sistemy na soznanie naroda $v$ gody Velikoy Otechestvennoy voyny: avtoref. dis. ... kand. ist. nauk [State-Legal and Ideological Influence of the State System on the Consciousness of the People during the Great Patriotic War]. Saint Petersburg, 2005. 25 p.

31. Khristoforov V.S. Stalingrad: Organy NKVD nakanune $i v$ dni srazheniya [Stalingrad: the NKVD before and during the Battle]. Moscow, OAO "Moskovskie uchebniki i Kartolitografiya", 2008. $240 \mathrm{p}$.

32. Shirokorad I.I. Tsentralnaya periodicheskaya pechat v gody Velikoy Otechestvennoy voyny (19411945) [Central Periodicals in the Years of the Great Patriotic War (1941-1945)]. Moscow, Izd-vo MGUP, 2001.330 p.

33. Yakunin V.N. Polozhenie i deyatelnost Russkoy pravoslavnoy tserkvi $v$ gody Velikoy Otechestvennoy voyny 1941-1945 gg. [For Faith and Fatherland: Activities of Russian Orthodox Church in the Great Patriotic War]. Samara, Izd-vo "Samarskiy un-t", 2001.400 p.

34. Yakunin V.N. Dukhovnoe obrazovanie v Rossii v gody Velikoy Otechestvennoy voyny [Spiritual Education in Russia during the Great Patriotic War]. Pedagogika, 2003, no. 1, pp. 88-91. 
Г.А. Куманев, Б.У. Серазетдинов. Историография изучения агитационно-пропагандистской работы

\section{Information about the Authors}

Georgiy A. Kumanev, Academician of RAS, Doctor of Sciences (History), Professor, Chairman of the Scientific Council at the Presidium of RAS on Problems of Military History, Head of Centre for Military History of Russia, Institute of Russian History of Russian Academy of Sciences, Dmitriya Ulyanova St., 19, 117036 Moscow, Russian Federation, voencentririran@yandex.ru, https://orcid.org/0000-0002-3399-3366

Boris U. Serazetdinov, Candidate of Sciences (History), Associate Professor, Honorary Worker of Higher Professional Education of the Russian Federation, Academic Secretary of the Scientific Council at the Presidium of RAS on Problems of Military History, Leading Researcher of the Centre for Military History of Russia, Institute of Russian History of Russian Academy of Sciences, Dmitriya Ulyanova St., 19, 117036 Moscow, Russian Federation, sbu54@bk.ru, https://orcid.org/0000-0001-7730-2769

\section{Информация об авторах}

Георгий Александрович Куманев, академик РАН, доктор исторических наук, профессор, председатель Научного совета при Президиуме РАН по проблемам военной истории, руководитель Центра военной истории России Институга российской истории РАН, ул. Дмитрия Ульянова, 19, 117036 г. Москва, Российская Федерация, voencentririran@yandex.ru, https://orcid.org/0000-0002-3399-3366

Борис Уразбекович Серазетдинов, кандидат исторических наук, доцент, почетный работник высшего профессионального образования РФ, ученый секретарь Научного совета при Президиуме РАН по проблемам военной истории, ведущий научный сотрудник Центра военной истории России Института российской истории РАН, ул. Дмитрия Ульянова, 19, 117036 г. Москва, Российская Федерация, sbu54@bk.ru, https://orcid.org/0000-0001-7730-2769 